\title{
State size and democratization in hybrid regimes: the Chinese island cities of Macau and Hong Kong
}

\author{
Ying-ho Kwong \\ Department of Politics and Public Administration, University of Hong Kong \\ u3005410@connect.hku.hk \\ Mathew Y.H. Wong \\ Department of Politics and Public Administration, University of Hong Kong \\ yhmwong@hku.hk
}

\begin{abstract}
The effect of state size on level of democratization has been a topic of interest to political scientists. However, studies have largely focused on democratic regimes, leaving unexplored the implications of state size for the regime persistence of hybrid regimes. This article compares two Chinese island cities with hybrid regimes through political analysis supplemented by interviews, and argues that a smaller regime is more likely to be authoritarian than a larger one. The case of Macau shows that the very small size of a 'microstate' helps central authorities to exercise political control, stifle political pluralism, and monopolize opinions, all of which strengthen regime persistence. In contrast, the case of Hong Kong shows that a merely 'small state', a larger political entity, creates political polarization, encourages political competition, and diversifies opinions, resulting in a more confrontational state-society relationship. This paper contributes to the literature by examining the effect of state size on regime persistence in hybrid regimes and explaining political development in Macau and Hong Kong from an alternative geopolitical perspective.
\end{abstract}

Keywords: China, democratization, Hong Kong, hybrid regimes, island cities, Macau, smallness, state size

https://doi.org/10.24043/isj.36

(C) 2017 — Institute of Island Studies, University of Prince Edward Island, Canada.

\section{Introduction}

Recent studies of island societies have recognized that there is a positive correlation between small state size and democratization (Anckar, 2006; Ott, 2000). However, the discussion has mainly focused on democratic regimes and on how small island societies can improve their level of political engagement and quality of democracy. Relatively little attention has been paid to the effect of state size on hybrid regimes, which are neither completely democratic nor fully authoritarian. Comparative studies on such regimes have argued that they largely tolerate opposition that may pose a challenge to their stability and that massive and violent repression is not a typical response. Rather, the key to maintaining "regime persistence" rests on building strong patron-client linkages to maintain political support and weaken opposition (Ottaway, 2003). Ott (2000, p. 99) suggested that "political interaction can be said to be greatly affected by small size, particularly in terms of how elites relate to one another and access for ordinary citizens to the political system." This study takes up the question of how state size affects the regime persistence of hybrid regimes.

Since the sovereignty transfers of 1997 and 1999, respectively, Hong Kong and Macau have transitioned from colonies to Special Administrative Regions (SARs) of China based on the principles of 'one country, two systems' (OCTS). The Hong Kong Special Administrative Region 
(HKSAR) and Macau Special Administrative Region (MSAR) retain hybrid regimes with limited electoral rights and a certain level of civil liberties. Sheng, Tang, and Grydehøj (2017) propose that one can regard Hong Kong and Macau as 'Chinese island cities' from an urban island studies perspective because of their island spatiality and historical development in China's Pearl River Delta. The present regimes of Hong Kong and Macau can therefore each be classified as 'sub-national hybrid regimes' (Fong, 2017).

Although both SARs have distinctive island characteristics and are located in the coastal area of southern China, their centre-periphery relationships are quite different: Hong Kong's is confrontational, whereas Macau's is harmonious. On the basis of a comparison of these two cases, this study argues that a small state with a hybrid regime is more likely to be authoritarian than is a larger state. The smallness of Macau facilitates central authorities' management of patron-client linkages and thereby promotes regime persistence, whereas the relatively large size of Hong Kong increases the difficulty of controlling opposition forces, leading to more confrontational state-society relations.

Theoretically, this article contributes to the literature on state size in the context of hybrid regimes. Empirically, the comparative analysis of Macau and Hong Kong enriches the existing literature by introducing an alternative geopolitical perspective. This article is organized into four sections. First, it reviews the literature on state size and hybrid regime trajectories. Second, the similarities and differences between Macau and Hong Kong are introduced. The third section compares the centre-periphery relationships in Hong Kong and Macau. Finally, this article analyzes the political implications of its arguments for these two island cities.

This paper mainly relies on qualitative research methods to analyze its two cases. First, we gathered original data in 2015 by conducting semi-structured interviews with opposition legislators and activists. Second, we conducted a content analysis of press reports to compare and contrast political events. Third, we systematically reviewed relevant documents from Statistics Departments and Electoral Affairs Commissions to enable first-hand data analysis. Finally, we used survey data to compare the political attitudes in the two island cities toward the central authorities.

\section{State size and hybrid regime trajectories: the theoretical context}

Studies commonly concur that small democratic states are more likely to remain democratic than their large counterparts (Anckar, 2006; Diamond \& Tsalik, 1999; Ott, 2000). This article defines 'state size' as population size within a territorial unit (Hey, 2003) and 'democracy' as a system of government that pursues "accountability" by emphasizing "systemic capacity" (state responsiveness to citizen preferences) and "citizen effectiveness" (citizen capability to affect state decisions) (Dahl \& Tufte, 1973). Much of the literature has recognized that small states are conducive to a higher quality of democracy because their size (1) enhances the level of political participation of and direct communication between politicians and citizens (Dahl \& Tufte, 1973), (2) increases social harmony and cohesiveness (Sutton, 2007), and (3) encourages consensus and accommodation (Srebrnik, 2004). Thus, in pioneering studies, Schumacher (1973) argued that "small is beautiful," and Ott (2000) used the proposal that "small is democratic" to explain why small states have higher degrees of democracy than larger ones.

Although the correlation between state size and degree of democracy in already democratic regimes is strong, the implications of state size for hybrid regimes have yet to be fully explored. According to Diamond (2002), the concept of a hybrid regime builds on Robert Dahl's framework of 'polyarchy', which regards civil liberties and electoral rights as two necessary dimensions of modern democracy. A regime is a 'full democracy' when both dimensions are fully present, and a regime is 'full authoritarian' when neither element is present. Thus, hybrid regimes, being regimes with both democratic and authoritarian elements, fill a gap between two polarizing regime types. In recent years, there has been more discussion of the implications of state size for "non-democratic regimes" (Veenendaal \& Corbett, 2015). This newfound interest is explained by the considerable number of hybrid and authoritarian regimes in the world. In the Freedom in the World report 
published by the Freedom House (2017), 87 (45\%) out of 195 countries were 'free' democratic regimes, 59 (30\%) were 'partly free' hybrid regimes, and 49 (25\%) were 'not free' authoritarian regimes. In other words, $55 \%$ of the world's countries were classified as non-democratic regimes. Leaders in those regimes pursue political control over territory to suppress political opposition and ultimately to achieve "regime persistence" (Brownlee, 2007). Some studies have thus recently begun to focus on the implications of state size for non-democratic regimes.

For example, Ott (2000, pp. 123-125) used quantitative methods to test whether small states are more likely to be authoritarian. He found that they are not for two reasons: (1) small states may be less attractive to authoritarian leaders (for instance, because they lack resources useful for personal gain), and (2) leaders in small states may not need to resort to authoritarian behaviors if certain institutions and mechanisms are already present and legal. In addition, Lundell (2012) argued that it is difficult to maintain autocratic rule in small states because problems shared among the people that are caused by limited territory, population, and resources tend to override ideological, economic, and ethnic concerns. Such shared problems, Lundell argued, foster and maintain democracy instead of authoritarianism. In short, these studies have argued that small states do not provide favourable conditions for authoritarian regimes.

However, there are some possible arguments for the opposite conclusion, namely that smallness can help to foster and maintain a non-democratic regime. Baldacchino (2012), for instance, pointed out that small social systems put more emphasis on personality politics, which can override other considerations, leading to patron-client relationships, nepotism, corruption, and pork barrels. A small setting helps an autocratic leader to monopolize and homogenize values, which increases the likelihood of authoritarianism and despotism. Veenendaal (2013) argued that smallness decreases the number and variety of political interests among the population and leads to less debate on political ideologies, so that small states feature less competition between ideologies for political influence. From this perspective, small states provide fertile ground for cultivating and maintaining authoritarianism.

Studies have largely agreed that the key to hybrid regime persistence is incumbents' capacity to build strong patron-client linkages (Ottaway, 2003). Strong linkages are conducive to maintaining political support and resisting political challenges, thereby improving regime persistence. In the absence of such linkages, significant political opposition to the regime is more likely, leading to political instability or even regime collapse (Levitsky \& Way, 2010). It is remarkable that patron-client linkages exist in different political regimes, ranging from democratic to authoritarian. The purpose of linkage building in democracies, however, is to create a loyal network of support for specific parties or politicians, whereas its purpose in non-democracies is to create socioeconomic dependence on the regime to maintain regime stability (Hicken, 2011). The notion of subnational democracy has been increasingly debated in recent years (e.g., Grydehøj, 2016). This study considers two cases of subnational hybrid regime to investigate how state size and patron-client linkages affect regime outcomes.

Based on the frameworks proposed by Ottaway (2003) and Levitsky and Way (2010), patronclient linkages can be analyzed in terms of three common indicators: (1) level of political control (extent to which pro-regime organizations control the society), (2) degree of political competition (extent to which parties or political groups can freely express opposition views), and (3) freedom of expression (extent to which the media environment is controlled). In the following sections, these three indicators are adopted to compare Macau and Hong Kong as Chinese island cities with hybrid regimes.

\section{Macau and Hong Kong as Chinese island cities: a brief comparison}

State size is a relative matter, and the qualification of a state as 'small' thus hinges on comparison to a large state (Goetschel, 1998). Macau and Hong Kong are located near the coast of southern China and are only $60 \mathrm{~km}$ from each other. With an area of $30.4 \mathrm{~km}^{2}$, Macau comprises the Macau Peninsula as well as the islands of Coloane and Taipa; whereas Hong Kong's 1,105.7 km² area comprises Hong Kong Island, the Kowloon Peninsula, and the New Territories. The two 
states have experienced rapid population growth since the 1980s, mainly due to the rising number of new migrants from mainland China. Currently, Macau hosts a population of 650,834, of whom 88.4\% are Chinese, whereas the figures for Hong Kong are 7,305,700, of whom 91\% are Chinese. The population density of Macau is around 21,400 people $/ \mathrm{km}^{2}$, whereas that of Hong Kong is around 6,600 people $/ \mathrm{km}^{2}$. Cantonese is the first language for $80.1 \%$ and $89.5 \%$ of the populations of Macau and Hong Kong, respectively. Overall, the population characteristics of both SARs are very similar, but Macau has fewer residents, a smaller area, and a higher population density than Hong Kong. According to Hey (2003), although smallness is not easily defined, one can generally count a state with fewer than 10 million people as small. For the purpose of this study, both Macau and Hong Kong are thus 'small states', but within this category, Macau can be further classified as a 'microstate' (population of less than 1 million) whereas Hong Kong should be regarded as a larger 'small state' (population of less than 10 million). Table 1 summarizes the territorial and demographic comparisons between Macau and Hong Kong.

Table 1: A comparison of Macau and Hong Kong.

$\begin{array}{lll} & \text { Macau } & \text { Hong Kong } \\ \text { Population } & 650,834 & 7,305,700 \\ \text { Land area }\left(\mathrm{km}^{2}\right) & 30.4 & 1,105.7 \\ \begin{array}{l}\text { Population density } \\ \left.\text { (people } / \mathrm{km}^{2}\right)\end{array} & 21,400 & 6,600 \\ \text { Ethnic groups } & & \\ & \text { Chinese: } 88.4 \% & \text { Chinese: } 91 \% \\ & \text { Other Asian: } 7 \% & \text { Other Asian: } 0.5 \%, \\ & \text { Portuguese: } 1.4 \% & \text { Others: } 8.5 \% \\ \text { Oanguages } & \text { Others: } 3.2 \% & \\ & \text { Cantonese: } 80.1 \% & \text { Cantonese: } 89.5 \% \\ & \text { Putonghua: } 5.5 \% & \text { Putonghua: } 1.38 \% \\ & \text { Other Chinese languages: } 5.3 \% & \text { English: } 3.5 \% \\ & \text { Portuguese: } 0.6 \% & \text { Others: } 5.59 \% \\ & \text { English: } 2.8 \% & \\ & \text { Others: } 3 \% & \end{array}$

Source: Macao Statistics and Census Services (2016, 2017); Census and Statistics Department of Hong Kong (2016, 2017).

Before Macau and Hong Kong became SARs of China, they had similar colonial experiences with western countries. Macau became a Portuguese colony in 1558 (during the Ming Dynasty), and Hong Kong became a British one in 1842 (during the Qing Dynasty). In 1972, Beijing formally removed the two territories from the list of colonies at the United Nations Committee on Decolonization, and the Chinese Communist Party started negotiations on decolonization arrangements for them. The Sino-Portuguese Declarations in 1987 and SinoBritish Declarations in 1984 stipulated that Macau and Hong Kong were to become SARs of China under the principles of OCTS in 1999 and 1997, respectively. According to the Declarations, both SARs were to enjoy a "high degree of autonomy" except in military and diplomatic affairs, which were to be the responsibility of the mainland Chinese government. Also, the Basic Law (the post-handover constitutional documents) granted the SARs executive, legislative, and judicial powers (including the power of final adjudication), and the two SARs would be governed by local inhabitants rather than mainland officials. Macau and Hong Kong are not similar merely in the sense of islandness (island cities off China's southern coast) and their colonial backgrounds, but also in their political systems design after the handover. This contributes to their value as comparative cases.

Macau and Hong Kong are interesting cases of hybrid regimes. The Portuguese and British governments created hybrid regimes in the two city-states during the colonial era. Political power 
was highly concentrated in the hands of colonial governors and some co-opted local elites, but the people were denied the right to elect their own governments. However, a certain level of civil liberties was protected. Since the transfers of sovereignty in 1997 and 1999, the governments of the HKSAR and MSAR have maintained their hybrid regime status with limited electoral rights and some civil liberties. Now, fewer than half of the seats (42.4\%) in the Legislative Assembly in Macau and half of the seats (50\%) in the Legislative Council in Hong Kong are chosen by direct elections. The Chief Executive's appointment system (21.2\%) still exists in Macau, but was abolished in Hong Kong in 2004. The Chief Executives, i.e., the heads of government, are handpicked by the Election Committees (400 members in Macau in a recent term, who were elected by 5,000 organization voters, and 1,200 members in Hong Kong in the current term, who were elected by more than 246,000 individual and organization/corporation voters), which are mainly controlled by the mainland.

Despite these similarities, there are some key differences between the constitutional documents for Hong Kong and Macau. The most obvious differences concern the election methods for the Chief Executive and the Legislative Council/Assembly. In Hong Kong, Article 45 states that the ultimate election method for the Chief Executive is to be 'universal suffrage', although the political reforms debated in 2015 reflected the Chinese government's systematic aim to control the composition of Election Committees and thereby to screen out non-Beijing-approved candidates before the popular election. However, there is no such promise of 'universal suffrage' in Macau, and its Basic Law only states that the Chief Executive is to be chosen by election or coordination (Article 47). As for the election methods for the legislature, Hong Kong's Basic Law promises that the ultimate goal is election of all members by universal suffrage (Article 68), but Macau's only states that the majority of members shall be "elected" (Article 68) (Ghai, 2000). Macau is comparatively less democratic than Hong Kong, but that has not been met with much resistance. Indeed, Macau has mostly been characterized by stability and a lack of popular dissatisfaction. In contrast, Hong Kong has experienced many critical political events motivated by resistance to political interventions from the mainland, such as the July 1 protest against a national security law in 2003 (participated in by 500,000 people), the Umbrella Movement in 2014, and the Mong Kok Riots in 2016 (involving a violent clash between the police and protesters). In the following section, the effect of state size and patron-client linkages will be examined in these two Chinese island cities.

\section{Patron-client linkages in two Chinese island cities: state size comparison}

As Baldacchino (2012, p. 107) argued, small is not always beautiful, as executive government in small polities is comparatively more powerful, which can undermine external checks and balances. In democratic states, smallness usually stimulates the development of patron-client relationships, thereby avoiding political conflicts and maintaining stability (Erk \& Veenendaal, 2014). In states with hybrid regimes, smallness can also help in managing state-society relations.

\section{Level of political control}

The founding of the People's Republic of China in 1949 created fear of communist rule that led to a wave of immigration to Hong Kong but not to Macau. The population of Hong Kong increased from 1.8 million in 1948 to 2.5 million by the mid-1950s (Wong et al., 2004), but no population change in Macau was evident (Shipp, 1997). In the 1960s, a huge number of refugees came to the two territories due to the outbreak of the Cultural Revolution in mainland China. In the face of this huge wave of immigration, the pro-Beijing organizations in Macau, mainly the business chambers and labour unions, were responsible for providing those immigrants with daily necessities and shelter, which alleviated negative perceptions of China and built strong social networks in the society. In Hong Kong, pro-Beijing organizations faced significant criticism for advocating riots in Hong Kong and consequently lost their credibility (Yep, 2008). Although the Chinese government did not have any official presence in the post-colonial era and had to rely on local pro-Beijing agents to exercise governing power in both states, the political outcomes differed. 
The fundamental reason for this difference is the role that small size and scale play in developing strong social networks, which promote despotism (Baldacchino, 2012). The literature has recognized that the Macau Special Administrative Region (MSAR) regime is ruled by a dominant pro-mainland coalition that includes political elites and social groups and entrenches formal and informal controls over society (Choi, 2010; Yu, 2013). Sheng (2016) argued that the limited size of Macau encourages more personal interaction than formal rules, while pro-mainland groups act as important middlemen for communication between government and the people. In fact, the close social connections help smooth society-state relations and bring about a superficial social harmony. Sheng (2016) also argued that Macau's smallness is conducive to social group politics and consensus building, which significantly affects the local political culture.

Building on Sheng's argument, we observe that there are three traditional social groups, namely the Macao Chamber of Commerce, the Macau Federation of Trade Unions (MFTU), and the General Union of Neighborhood Associations of Macau (GNA), which were set up in the colonial era to assist the governance of the post-handover MSAR government. In particular, both the MFTU and GNA mostly receive government subsidies for taking care of the interests of the working class (Choi, 2010). With the issuing of new casino licenses in the early 2000s, and the growth of the casino and construction industries, many casino and construction tycoons realized that they must be politically active to expand their political influence through elections. With ample financial resources, tycoons do not need to rely on government subsidies, and they can form or join different communal organizations to influence elections by giving huge private donations. These communal groups build up a network of community services and offer regular welfare, such as cash handouts, free meals, tours, shop discounts, and various material benefits in the name of "membership subsidies" (Kwong, forthcoming). The small population and territory of Macau provides a favourable platform for community networking in return for political support and has translated into more consensus-based and accommodative politics, which decreases challenges to the government. Thus, according to Au Kam-sun, an opposition legislator, this mixed set of government-subsidized and tycoon-subsidized social services makes residents feel satisfied with the status quo, which discourages demand for political reforms (interview with Au Kam-sun, 4 March 2015).

In Hong Kong, the comparatively larger population and area have made the exercise of political control by the Kong Kong Special Administration Region (HKSAR) government or other central authorities more difficult. The Democratic Alliance for the Betterment and Progress of Hong Kong (DAB), the flagship political party of the pro-mainland camp, exercises political control by participating in District Council Elections and focuses mainly on community services. In recent years, as a Beijing-sponsored party, $\mathrm{DAB}$ has used its donations and sponsorships from pro-mainland businessmen to distribute spoils, such as free meals and gifts, to grassroots voters (Fong, 2017). Currently, DAB holds 117 out of 431 (27.1\%) elected District Council seats. Yet although DAB holds the most seats in District Councils, and its resource advantages help it to defeat the opposition, it does not exert as much political control as its counterparts in Macau.

One explanation for this comparative lack of control is the growing disconnection of the business sector from the local community (Fong, 2013). In the colonial era, local Chinese capitalists were highly regarded and recognized as the leaders of the Chinese community, with high credibility and strong reputations. In turn, they developed their own community networks in various district and welfare organizations. After the handover, these business elites have generally been able to gain privileged political power in various institutions, so they are generally reluctant to take part in general elections or organized political parties. With limited community networks and connections to civil society, business elites can no longer consider themselves 'leaders' and are unable to mobilize public opinion or support and to protect the HKSAR authority from political challenges (Fong, 2013). At the same time, the leaders of current pro-regime parties like DAB likewise lack the kind of credibility that business leaders had in the colonial era. Thus, Hong Kong's comparatively larger area and population lead to more stakeholders and divided interests, making consensus building more difficult to achieve. 


\section{Degree of political competition}

The literature has suggested that smallness encourages homogeneity of opinion and the absence of ideological cleavages, depressing the level of political competition (Veenendaal, 2013). This argument also applies to the two island cities under investigation. After the handover, pro-mainland forces displaced the colonial governments in the SARs and now dominate politics through the influence they wield in political institutions. The Chief Executive of the MSAR is elected by a 400-member election committee. Most of its members are selected by social groups, but there is virtually no competition for the selection of these members. Informal negotiations for nomination in the 'black box' avoid competition and ensure that pro-mainland members dominate the committee $(\mathrm{Yu}, 2013)$. Up until now, not a single supporter of the opposition has joined the committee, let alone been a candidate in the election for the Chief Executive.

In Hong Kong, the Chief Executive is elected by a 1,200-member election committee, also dominated by the pro-mainland camp. However, compared with Macau, the difference in the degree of political competition is obvious. Alan Leong from the Civic Party and Albert Ho from the Democratic Party, two former pro-democratic legislators, ran against the pro-mainland candidates in the 2007 and 2012 elections. In the most recent election in 2017, the opposition camp won more than 300 seats on the committee, mainly from the professional (e.g., higher education and law) and social service (e.g., social welfare) sectors, and was able to nominate at least one pro-opposition candidate in the election for the Chief Executive (although they declined to do so). Macau's relative smallness provides a better environment for pro-mainland groups to coordinate in marginalizing ideological opposition, whereas Hong Kong's larger size increases the difficulty for pro-mainland forces to coordinate. This increases the diversity of interests represented in Hong Kong's system, which leads to greater ideological competition.

Competition is generally more intense in legislative elections. Although pro-mainland forces control legislative majorities in both island cities, $42 \%$ of seats in Macau's Legislative Assembly are directly elected by all voters, and half of the seats in the Hong Kong Legislative Council are returned through geographical constituencies (direct elections). Table 2 shows a comparison of the overall election results. In the election of September 2017, the ratio of the number of nominated lists to that of registered voters was 1:12,793 in Macau, whereas that ratio in Hong Kong's election of 2016 was 1:44,989. Those numbers reflect the higher competitiveness of the Hong Kong election. The list-voter ratio in Macau fluctuated from 2001 to 2017 but has not significantly deviated from around 1:13,000. However, in Hong Kong, the ratio gradually decreases from $1: 84,872$ in 2000 to $1: 44,898$ in 2016 , partly due to the proliferation of new pro-mainland and opposition parties. This indicates that (1) more new groups were willing to take part in Hong Kong's election than in Macau's, and (2) more of Hong Kong's established political parties strategically assigned more lists to join the election than did Macau's. With respect to legislature composition, in Macau, the ratio between pro-mainland and pro-opposition parties from 2013 to 2017 was 3.5:1. In Hong Kong, which has a more diverse group of opposition parties, this ratio is currently $0.5: 1$. To a certain extent, this reflects a comparative lack of new parties or groups from either camp that can compete in the Legislative Assembly Elections in Macau, whereas there is no such lack in Hong Kong's Legislative Council Elections. According to Wong (forthcoming), a larger legislature allows the opposition to participate without any significant effect and widens income inequality. It forces the opposition to turn more radically against the authorities. The relatively large number of opposition members (30 out of 70 legislators in 2016) in Hong Kong's Legislative Council results in more conflicts within the legislature, but the small number (4 out of 33 legislators in 2013) of opposition members in Macau's legislature renders them very moderate. 


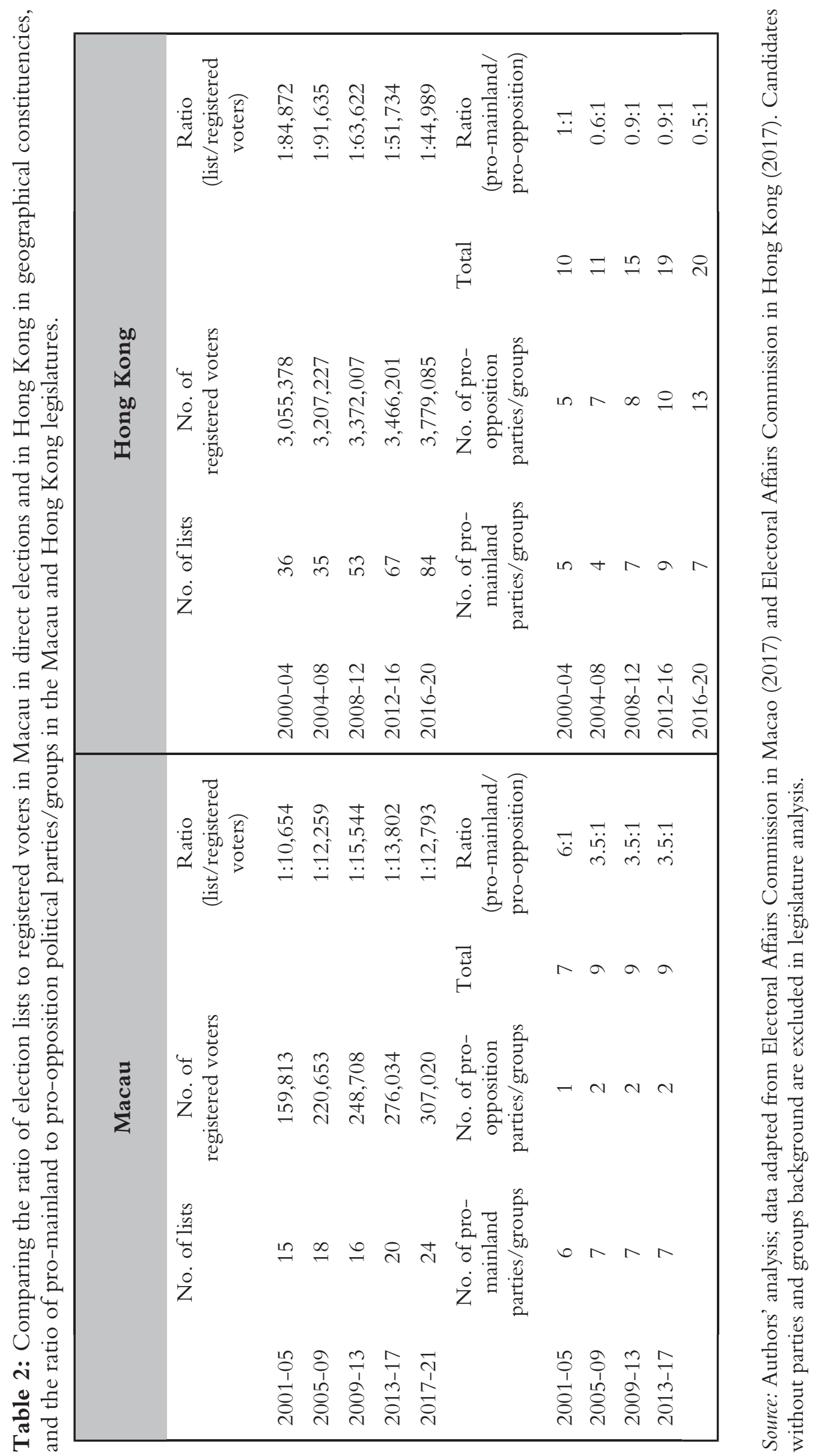


Recently, negative feelings toward mainlanders have contributed to the rise of localism in Hong Kong (Ma, 2015). These new ideological sentiments have developed because of rising tensions between the mainland and the HKSAR, increasing affirmation of local identity, and growing dissatisfaction with the ideologies of traditional pro-democrats. To protect Hong Kong's autonomy, localists have demanded not only political reform but also the right to self-determination through referenda, or even independence from the mainland. Some localist groups such as Civic Passion and Demosisto have participated in legislative elections and captured some seats. Thus, the political landscape is now divided among mainland loyalists, pro-democrats, and the localist camp.

However, the opposition groups in Macau recognize that smallness does not favour the development of new ideologies. According to Ng Kuok-cheong, an opposition legislator, "Macau is a small society, and residents tend to have a close relationship with others, so people who openly make critical comments or espouse democratic ideologies may be in danger of losing their jobs and affecting their family members, or even losing their access to the mainland" (interview with Ng Kuok-cheong, 3 March 2015). Ng personally lost his job in a Chinese-owned bank due to political pressure from the authorities in the early 1990s. Also, the small size of Macau's economy makes it easier for the authorities to hinder the opposition through other means. Sulu Sou, a young democratic activist, said:

To repress opposition groups, in the 1980s, construction companies kept a 'blacklist' of all labour activists, whom the companies would not employ because of ideological considerations. More recently, many big casino companies and government officials have also refused to employ activists. Although most younger people are more educated nowadays, many of them, especially professionals, are still afraid to voice their support for opposition ideologies, because it may affect their careers. (Interview with Sulu Sou, 24 February 2015)

Thus, Macau's small size makes it comparatively difficult for people to suggest or adopt new ideological orientations.

Freedom of the press

Some have argued that the small size of a state leads to low quality of news reporting, as the number of professional journalists is limited, and media companies serving small markets unavoidably face a lot of difficulties in their operations (Erk \& Veenendaal, 2014). According to the hybrid regime literature, politicians commonly manipulate media content in favour of incumbents to limit opposition. To manipulate the media, incumbents can either bring about and take advantage of direct state ownership of media or exercise indirect influence through pro-regime businessmen who own and control media corporations. Both Macau and Hong Kong face the problem that the mainland and local authorities monopolize and control the media between them, which makes self-censorship a serious problem (Fong, 2017; Yu, 2013). However, Hong Kong still enjoys a greater degree of press freedom than Macau with respect to coverage of ideologies different from the official ones.

The ratio of pro-mainland to pro-opposition political positions in print and online news sources in the two territories is analyzed here. Nearly all major newspapers in Macau take a pro-mainland stance (8:1), whereas the ratio is smaller (4:1) in Hong Kong. In both cities, media tycoons have traditionally been targets of 'united front' works from the mainland. The larger ratio in Macau reflects the ownership of most Macau newspaper companies by the mainland government or pro-mainland businessmen, giving a near monopoly to pro-mainland messages. The figures for Hong Kong indicate that there are still some differing ideological views expressed in print media. Although most Hong Kong newspaper companies are likewise owned and run by the mainland government or pro-mainland businessmen, there is much more room for expressing different ideologies in Hong Kong than in Macau. Yet one can argue that traditional 
media are pro-establishment by nature, whereas online news media are supposed to report "alternative news" that can challenge the "hegemonic power" of mainstream media (Couldry \& Curran, 2003). Even so, the freedom of online press in Macau is still comparatively limited. In Hong Kong, the ratio of pro-mainland to pro-democracy online news sources is $0.6: 1$, meaning that there are more pro-opposition online news sources than pro-mainland ones. Opposition groups in Hong Kong also use the internet in addition to traditional media to express their ideology and to criticize the government. However, the same ratio in Macau is 1:1, which means that the number of pro-opposition online news sources is comparable to that of pro-mainland sources.

The analysis shows that the small size of a society can stifle media pluralism. This finding is consistent with those of Veenendaal and Corbett (2015) that whereas media are considered key avenues for forcing governments to be accountable in large states, press independence is harder to sustain in small states with different economies of scale. In Hong Kong, the daily newspapers are mostly government-affiliated, but the larger population can provide more financial and human resources to support online news media, which promotes diversified opinions. In Macau, however, both traditional and online news media are dominated by the state due to the smaller population size. As suggested by Jason Chao, the founder of Macau Concealer, an opposition online news source:

Macau is a small community. We don't receive huge financial subsidies from the government like those that the mainstream media receive. We only have one full-time staff in our office and mainly rely on subsidies from opposition groups and supporters. The support is obviously limited. (Interview with Jason Chao, 26 February 2015)

Thus, censorship in Macau is common, and most media outlets refrain from criticizing the authorities.

\section{State size and political consequences in two states with hybrid regimes}

In the two SARs under the authoritarian regime of China, local agents of that regime are responsible not only for exercising governing power but also for promoting trust in mainland authorities and making arrangements to maintain political support. Following the above analysis, small states tend to be easier to control through patron-client linkages, whereas large states are more pluralistic. Patron-client linkages have the important function of maintaining political support and weakening the opposition, which ultimately affects regime trajectories (Ottaway, 2003). Nevertheless, different political consequences in the two cities are observable, namely with respect to nationalist sentiments (a feeling of trust) and counter-movements (political suppression).

Figures 1 and 2 present the net value of trust in the mainland and local authorities, and confidence in the OCTS in Macau and Hong Kong, respectively. According to the 2016 annual survey by the University of Hong Kong Public Opinion Programme, a net (share of negative subtracted from positive) of $65 \%$ of respondents in Macau indicated that they are confident in the policies of OCTS and "Macau people ruling Macau." Macau residents also demonstrated rather positive trust attitudes toward both mainland (net value $=50.7 \%$ ) and local (net value $=$ 49\%) authorities. Although the figures have fluctuated in recent years, the overall trend is still steady and highly positive. Based on the same survey conducted in Hong Kong, however, the net confidence in OCTS and trust in the local authorities was less than 5\% in 2016. For trust toward the mainland state, the net value was even negative $(-7.6 \%)$, meaning that more people were distrustful of the mainland authorities than trustful. The overall trend in the past decade also shows that all three attitudes are clearly on a decline. Based on these figures, Macau residents are currently likely to have much more positive attitudes toward both mainland and city authorities and their governance arrangements than their counterparts in Hong Kong. 
Figure 1: Net values of trust in mainland and local city authorities and of confidence in OCTS in Macau.

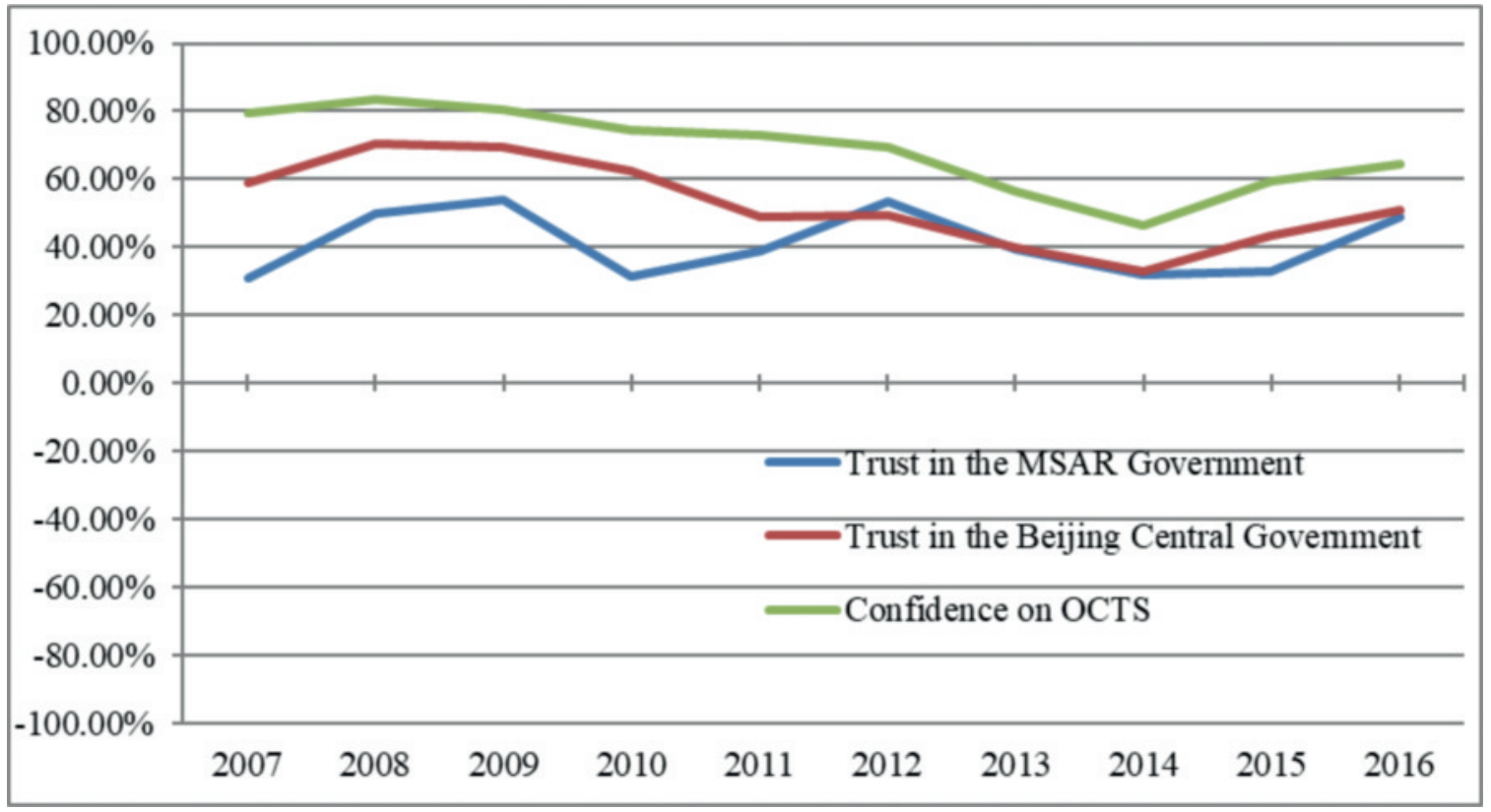

Source: Public Opinion Programme, University of Hong Kong, various years.

Figure 2: Net values of trust in mainland and local city authorities and of confidence in OCTS in Hong Kong.

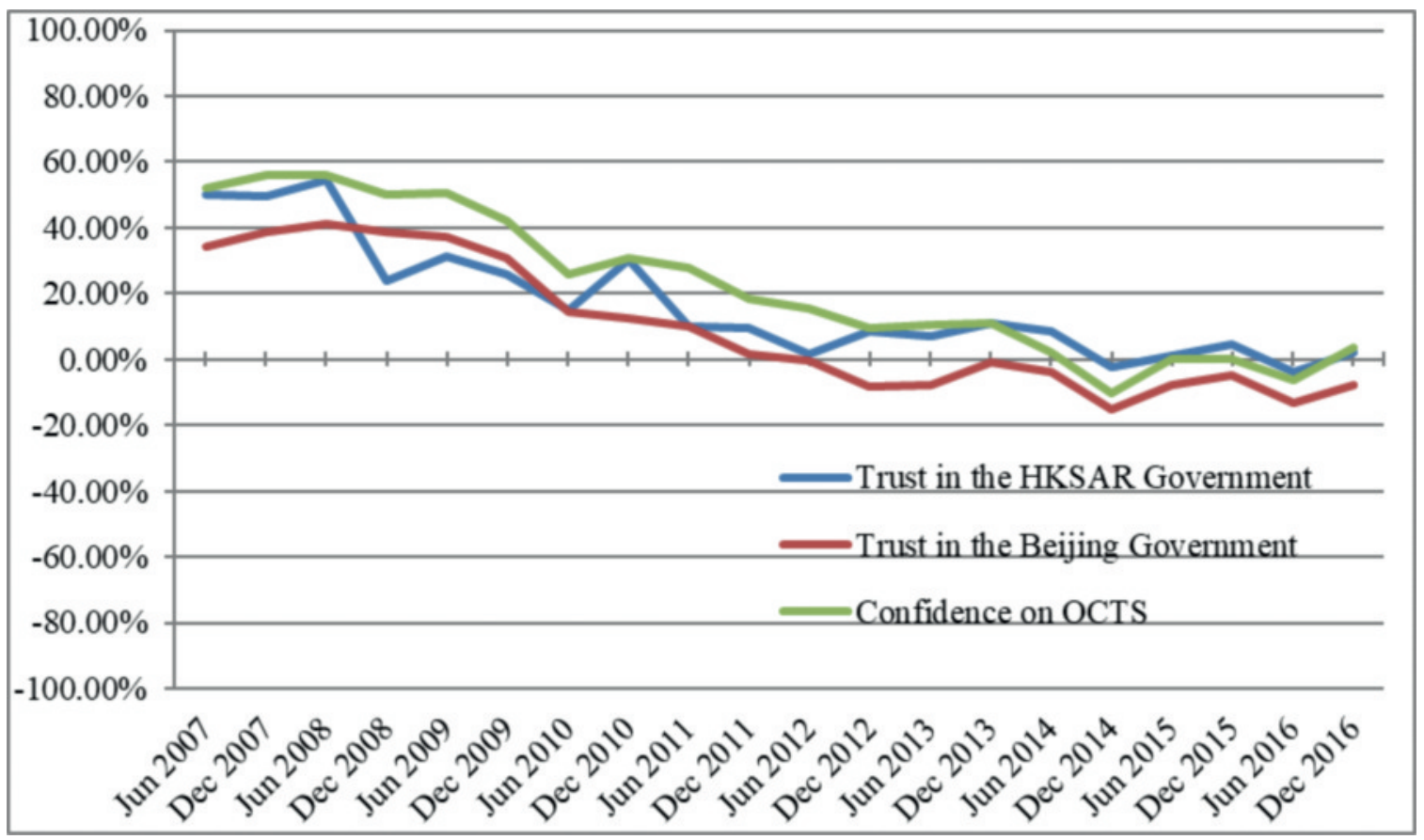

Source: Public Opinion Programme, University of Hong Kong, various years. 
The strong patron-client network in Macau is perhaps a key reason for the difference. Macau's small size favours the building of strong networks that can mobilize their members to support the Beijing and MSAR governments. Those associations organize events to legitimize policies, support the government, and promote nationalism. For some politically sensitive issues such as the national security legislation (highly controversial in Hong Kong but not in Macau) and the political reform of 2012, various associations have organized sessions or carnivals in support of the proposals, creating an environment favourable for their passage. However, this same social network is quite difficult to build in Hong Kong because of its larger size. Although pro-mainland groups similarly try to mobilize, their effect on political outcomes is minimal. The result is more diversified opinions, challenges to the authorities, and a more conflicted state-society relationship.

\section{Conclusion}

Existing literature on island states suggests that small states are more likely to be democratic (Anckar, 2006; Ott, 2000). For good reason, most studies focus on democratic regimes. In this article, we examine two hybrid regimes and attempt to provide new insights on the relationship between state size and regime persistence. Through a comparison of two Chinese island cities with hybrid regimes, this article shows that under some circumstances, small states can be more authoritarian than larger ones.

The cases of Macau and Hong Kong support our arguments. Based on population size, we regard Macau as a 'microstate', whereas Hong Kong is merely a 'small state'. Macau's smaller size permits incumbents to build strong patron-client linkages by exercising political control, discouraging other ideologies, and fostering a monopoly of pro-regime opinions in news media. In short, smallness can stifle pluralism (Veenendaal \& Corbeett, 2015), making the community more susceptible to state control and facilitating regime persistence. However, Hong Kong's larger size makes the building of such linkages more difficult, resulting in more political polarization, competition, and conflicts. The failure of linkage building further leads to a confrontational state-society relation and strong challenges to the legitimacy of the Hong Kong government.

This article complicates the traditional belief that small democratic regimes tend to maintain democracy (Ott, 2000) by suggesting that small hybrid systems tend to favour the extant regime. This article also strengthens our understanding of politics in Hong Kong and Macau. In the earliest post-colonial era, "colonial legacies" were a common approach to comparing the political environments in the two territories (Chan, 2003; Lo, 2007). Now that around 20 years have passed since the transfer of sovereignty, coalition-opposition dynamics has become the most popular approach to explain governance outcomes in the literature. The mainstream perspective highlights that Macau has a strong pro-mainland governing coalition and weak opposition ( $\mathrm{Yu}$, 2013), whereas Hong Kong is characterized by a strong opposition and weak governing coalition (Fong, 2013), which explains the distinct political outcomes in the two cases.

According to Baldacchino (2012), the manageability of island spaces promotes and nurtures dispositions to domination and control over society. State size can be understood to partially determine the positions and strengths of ruling elites and opposition groups. This paper thus makes an important and original contribution to the existing literature by going beyond coalition-opposition dynamics explanations, namely by highlighting the role of state size. In addition, the paper offers an alternative geopolitical perspective for understanding political outcomes in the two Chinese island cities.

\section{Acknowledgements}

We would like to acknowledge the funding support provided by the Seed Funding Programme, University of Hong Kong. We are grateful to Ms. Wing-yung Lai for providing research assistance. 


\section{References}

Anckar, D. (2006). Islandness or smallness? A comparative look at political institutions in small island states. Island Studies Journal, 1(1), 43-54.

Baldacchino, G. (2012). Islands and despots. Commonwealth \& Comparative Politics, 50(1), 103-120. https://doi.org/10.1080/14662043.2012.642119

Brownlee, J. (2007). Authoritarianism in an age of democratization. Cambridge: Cambridge University Press. https://doi.org/10.1017/CBO9780511802348

Census and Statistics Department of Hong Kong. (2016). Hong Kong Annual Digest of Statistics 2016. Hong Kong: Census and Statistics Department of Hong Kong.

Census and Statistics Department of Hong Kong. (2017). Hong Kong-The Fact. https://www.gov.hk/en/about/abouthk/facts.htm

Chan, M.K. (2003). Different roads to home: the retrocession of Hong Kong and Macau to Chinese sovereignty. Joumal of Contemporary China, 36(12), 493-518. https://doi.org/10.1080/10670560305473

Choi, A.H. (2010). Intergovernmental relations between mainland China and the Macao SAR. In A. Hicken (Ed.), Politics of modern southeast Asia: critical issues in modern politics (pp. 475-499). London \& New York: Routledge. https://doi.org/10.1201/b10266-29

Couldry, N., \& Curran, J. (2003). Contesting media power. Lanham: Rowman \& Littlefield.

Dahl, R. A., \& Tufte, E. R. (1973). Size and democracy. Stanford: Stanford University Press.

Diamond, L. (2002). Thinking about hybrid regimes. Journal of Democracy, 13(2), 21-35. https://doi.org/10.1353/jod.2002.0025

Diamond, L.J., \& Tsalik, S. (1999). Size and democracy: the case of decentralization. In L.J. Diamond (Ed.), Developing democracy: towards consolidation (pp. 117-160). Baltimore: The John Hopkins University Press.

Electoral Affairs Commission in Hong Kong (2017). Legislative Council Elections. http://www.eac.gov.hk/en/legco/lce.htm

Electoral Affairs Commission in Macao (2017). Legislative Council Elections. http://www.eal.gov.mo/zh tw/committee.html

Erk, J., \& Veenendaal, W. (2014). Is small really beautiful? the microstate mistake. Journal of Democracy, 25(3), 135-148. https://doi.org/10.1353/jod.2014.0054

Fong, B. (2017). In-between liberal authoritarianism and electoral authoritarianism: Hong Kong's democratization under Chinese sovereignty, 1997-2016. Democratization, 24(4), 724-750. https://doi.org/10.1080/13510347.2016.1232249

Fong, B.C.H. (2013). State-society conflicts under Hong Kong's hybrid regime: governing coalition building and civil society challenges. Asian Survey, 53(5), 854-882. https://doi.org/10.1525/as.2013.53.5.854

Freedom House (2017). Freedom in the world 2017. New York: Freedom House. https://freedomhouse.org/sites/default/files/FH FIW 2017 Report Final.pdf

Ghai, Y. (2000). The Basic Law of the Special Administrative Region of Macao: some Reflections. The International and Comparative Law Quarterly, 49(1), 183-198. https://doi.org/10.1017/S0020589300064022

Goetschel, L. (1998). The foreign and security policy interests of small states in today's Europe. In L. Goetschel (Ed.), Small states inside and outside the European Union: interests and policies (pp. 13-32). Boston: Kluwer Academic. https://doi.org/10.1007/978-1-4757-2832-3 2

Grydehøj, A. (2016). Toward subnational democracy of scale: tensions between democratic legitimacy, legality and effective governance. Geopolitics, 21(1), 22-42. https://doi.org/10.1080/14650045.2015.1114918

Hey, J.A.K. (2003). Introducing small state foreign policy. In J. A. K. Hey (Ed.), Small state in world politics: explaining foreign policy behavior (pp. 1-12). Boulder \& London: Lynne Rienner.

Hicken, A. (2011). Clientelism. Annual Review of Political Science, 14, 289-310. https://doi.org/10.1146/annurev.polisci.031908.220508 
Kwong, Y.H. (forthcoming). Ruling coalition restructuring under Macao's Hybrid Regime. China Review.

Levitsky, S., \& Way, L. (2010). Competitive authoritarianism: hybrid regimes after the Cold War. Cambridge: Cambridge University Press. https://doi.org/10.1017/CBO9780511781353

Lo, S.S.H. (2007). One formula, two experiences: political divergence in Hong Kong and Macao. Journal of Contemporary China, 16(2), 359-387.

Lundell, K. (2012). Determinants of dictatorship: a comparison of enduring and former autocracies. In C. Anckar \& D. Anckar (Eds.), Comparisons, regimes, elections: Festschrift for Lauri Karvonen (pp. 179-202). Åbo: Åbo Akademi University Press.

Ma, N. (2015). The rise of 'anti-China' sentiments in Hong Kong and the 2012 Legislative Council Elections. China Review, 15(1), 39-66.

Macao Statistics and Census Services (2016). Year of Statistics 2015. Macao: Macao Statistics and Census Services. $\quad$ http://www.dsec.gov.mo/Statistic.aspx?lang=enUS\&NodeGuid $=\mathrm{d} 45 \mathrm{bf} 8 \mathrm{ce}-2 \mathrm{~b} 35-45 \mathrm{~d} 9-\mathrm{ab3a}-\mathrm{ed} 645 \mathrm{e} 8 \mathrm{af} 4 \mathrm{bb}$

Macao Statistics and Census Services (2017). Results of 2016 population by-census. Macao: Macao Statistics and Census Services. http://www.dsec.gov.mo/getAttachment/bfa0112a-eaf349a9-9168-b5add46e9d65/C ICEN PUB 2016 Y.aspx

Ott, D. (2000). Small is democratic: an examination of state size and democratic development. New York \& London: Garland.

Ottaway, M. (2003). Democracy challenged: the rise of semi-authoritarianism. Washington: Carnegie Endowment for International Peace.

Public Opinion Programme, University of Hong Kong. (various years). Macau annual survey. https://www.hkupop.hku.hk/chinese/popexpress/macau/index.html

Public Opinion Programme, University of Hong Kong. (various years). Pop polls. https://www.hkupop.hku.hk/chinese/popexpress/macau/index.html

Schumacher, E.F. (1973). Small is beautiful. London: Blond \& Briggs.

Sheng, L. (2016). The transformation of island city politics: the case of Macau. Island Studies Journal, 11(2), 521-536.

Sheng, N., Tang U.W., \& Grydehøj, A. (2017). Urban morphology and urban fragmentation in Macau, China: island city development in the Pearl River Delta megacity region. Island Studies Journal, 12(2). https://doi.org/10.24043/isj.25

Shipp, S. (1997). Macau, China: a political history of the Portuguese colony's transition to Chinese rule. Jefferson \& London: McFarland \& Company.

Srebrnik, H. (2004). Small island nations and democratic values. World development, 32, 329-341. https://doi.org/10.1016/j.worlddev.2003.08.005

Sutton, P. (2007). Democracy and good governance in small states. In E.J. Kisanga \& S.J. Danchie (Eds.), Commonwealth small states: issues and prospects (pp. 201-217). London: Commonwealth Secretariat.

Wong, M.Y.H. (forthcoming). Legislature size and inequality: democratic participation and authoritarian dilution. Political Science. Online first.

Wong, L., White, L. T., \& Gui, S. X. (2004). Social policy reform in Hong Kong and Shanghai: a tale of two cities. Armonk: M.E. Sharpe.

Veenendaal, W. (2013). Size and personalistic politics: characteristics of political competition in four microstates. The Round Table, 102(3), 245-257. https://doi.org/10.1080/00358533.2013.794582

Veenendaal, W., \& Corbett, J. (2015). Why small states offer important answers to large questions. Comparative Political Studies, 48(4), 527-549. https://doi.org/10.1177/0010414014554687

Yep, R. (2008). The 1967 Riots in Hong Kong: the diplomatic and domestic fronts of the colonial governor. China Quarterly, 193, 122-139. https://doi.org/10.1017/S0305741008000076

Yu, E.W.Y. (2013). Macao's 'One Country, Two Systems': high autonomy or intervention? In R. Yep (Ed.), Negotiating autonomy in Greater China: Hong Kong and its sovereign before and after 1997 (pp. 207-241). Copenhagen: NIAS Press. 